\title{
Metallurgical Wastes Employed as Catalysts and Photocatalysts for Water Treatment: A Review
}

\author{
Claudia Victoria Montoya-Bautista ${ }^{1}$, Edwin Avella ${ }^{1}$, Rosa-María Ramírez-Zamora ${ }^{1, *}$ \\ and Rafael Schouwenaars ${ }^{2, *}$ \\ 1 Instituto de Ingeniería, Coordinación de Ingeniería Ambiental, Universidad Nacional Autónoma de \\ México (UNAM), Mexico City 1910, Mexico; claudia.montoya.b@gmail.com (C.V.M.-B.); \\ EAvellaF@iingen.unam.mx (E.A.) \\ 2 Facultad de Ingeniería, Departamento de Materiales y Manufactura, Universidad Nacional Autónoma de \\ México, Mexico City 1910, Mexico \\ * Correspondence: rramirezz@iingen.unam.mx (R.-M.R.-Z.); raf_schouwenaars@yahoo.com (R.S.)
}

Received: 22 March 2019; Accepted: 23 April 2019; Published: 26 April 2019

check for updates

\begin{abstract}
Metallurgical slags are a mass-produced industrial solid waste, often destined to landfills; the volumes disposed represent an environmental burden. Over the last three decades, applications have been found for these wastes, mainly as a low-cost additive in building materials. More recently, their unique chemical properties have attracted attention to produce high-added-value materials for environmental applications, to be used as adsorbents, catalysts, or a source of reactive species in environmental engineering. Such uses can be classified as a function of the added value generated, technological complexity, and environmental impact. This review will focus specifically on the modification and use of slags for catalysis, photocatalysis, and photocatalytic production of hydrogen, which have received relatively little attention in literature. A summary will be presented about the general requirements for using unmodified slags as well as slag processed under alkaline or acidic conditions for advanced oxidation processes. Then, an overview will be given of the use of slags as photocatalysts in water treatment, organized according to the origin of the product (steel, copper, magnesium, ferromanganese), as well as emerging reports on the photocatalytic production of hydrogen, in contrast to the use of highly specific titania-based products developed for the same purpose.
\end{abstract}

Keywords: metallurgical wastes; slag; low-cost catalyst; water treatment; hydrogen production; valorization

\section{Introduction}

Slag is the solidified or fused residue of high-temperature industrial processes. The term includes the noncombustible fraction remaining from waste incineration [1-4] and solid biofuels [5,6]. Waste materials can also be combined and heat-treated to reproduce the useful properties of blast furnace slag [7] in a synthetic product. While there is a considerable body of literature focusing on management, recycling, and valorization of these products, the present work will limit itself to metallurgical slag which is produced during the extraction and refinement of metals from their ores. These slags are divided into nonferrous and ferrous slag, with the latter subdivided into blast surface slags, steel slags, and alloy steel slags. Current valorization strategies may differ significantly between the different categories and feasibility depends strongly on the specific physical and chemical characteristics of the product.

Iron and steel slag present the most important volume of metallurgical wastes produced worldwide, estimated at $400 \mathrm{Mt} /$ year [8], and have been studied intensively in terms of recycling and valorization. 
Most recycling strategies correspond to low-technology, high-volume applications. Slag with low Ca content is commonly used as fine and/or coarse aggregates for cement and concrete [9-11]. Basic Oxygen Furnace (BOF) slag is used frequently as a partial substitute in Portland cement [12-14], where it allows obtaining enhanced properties in terms of resistance to aggressive environments [15]. Reviews of the use of steel slag in phosphorus removal from agro-industrial wastewater streams are available [16,17]. The use of metallurgical slag to treat contaminated point-sources of industrially and naturally contaminated surface and ground water was summarized by Mercado-Borrayo et al. [18]. Specific studies have been presented on the characterization of different slags for the removal of B and As [19], removal of As III and V [20], and comparison of slag with commercial resins for B removal [21]. $\mathrm{CeO}_{2}$ nanoparticles were found to be more efficient than slag in the removal of heavy metals [22], but the slag-based process is much more economic, which facilitates its upscaling toward pilot applications. None of the former involve catalysis, as the slag serves as a source for the slow release of alkaline ions which provoke the coprecipitation of the contaminant ions on the slag surface.

A particular application of iron slag is water splitting under solar irradiation by using the oxidation of wüstite, as described by Shatokha et al. [23]. Contrary to the methods mentioned in Section 3 of this review, this is not a catalytic process, as the wüstite is transformed into magnetite, which can be valorized as a resource for iron production or may have high added value by itself. Hydrogen production in the process is considered sufficient to be used in the reduction process of iron from its ores. The study distinguishes itself from other works cited in this review by presenting an advanced thermodynamic analysis of the processes involved.

Copper slag is a waste product from the extractive metallurgy of copper. For each ton of metal produced, 2.2 to $3 \mathrm{t}$ of slag is generated [24,25], with the worldwide annual production estimated at $68 \mathrm{Mt}$ [26]. Although it is sometimes classified as a hazardous waste [27], leaching tests do not show the release of heavy metals $[28,29]$. Historically, copper recuperation from its ores was less efficient than in modern processes and copper slag is often recycled for the recuperation of metal residues [23,30], or even as an alternative source for iron [31]. Such applications are a form of waste valorization, but do not fall into the category of recycling as large volumes of solid residuals remain after the process and new slag materials may be generated. As is the case of iron and steel slags, copper slags are used as aggregates in cements and concretes [25,32-35], road surfaces, and abrasives [36,37].

Magnesium slag is produced by the Pidgeon process for the silicothermic reduction of magnesium oxide and is rich in iron and silica. Worldwide Mg production in 2017 was about 1.1 Mt [38]. Each ton of magnesium produced corresponds to the generation of 6 to $7 \mathrm{t}$ of slag. Although applications in cementitious materials exist, these are not as widespread as is the case of steel slag [39,40]. Alternative uses are therefore investigated, such as the production of photocatalysts.

Silicomanganese is used as an alloying addition in iron and steel production. Its use in Portland cement [41] and Portland cement with addition of fly ash [42] was reported by Nath and Kumar. A lower volume application, but with higher added value and technological complexity, is its development as a welding slag [43] used in mining equipment [44]. Its development as a photocatalyst will be described in Section 3.4.

When considering the different applications summarized above, several levels of slag reutilization can be distinguished (Figure 1). Although the classification provided here is proposed by the authors, Yi et al. [45] use a similar subdivision in their review on steel slag utilization. At the lowest level of sophistication, the waste is used as an aggregate or a filler, usually in construction materials, with the goal of getting rid of it without recurring to landfilling. Nonetheless, the environmental benefit is double. Besides reducing the volume to be disposed of, the waste material substitutes for other resources, which very often would be produced by mining or quarrying. 


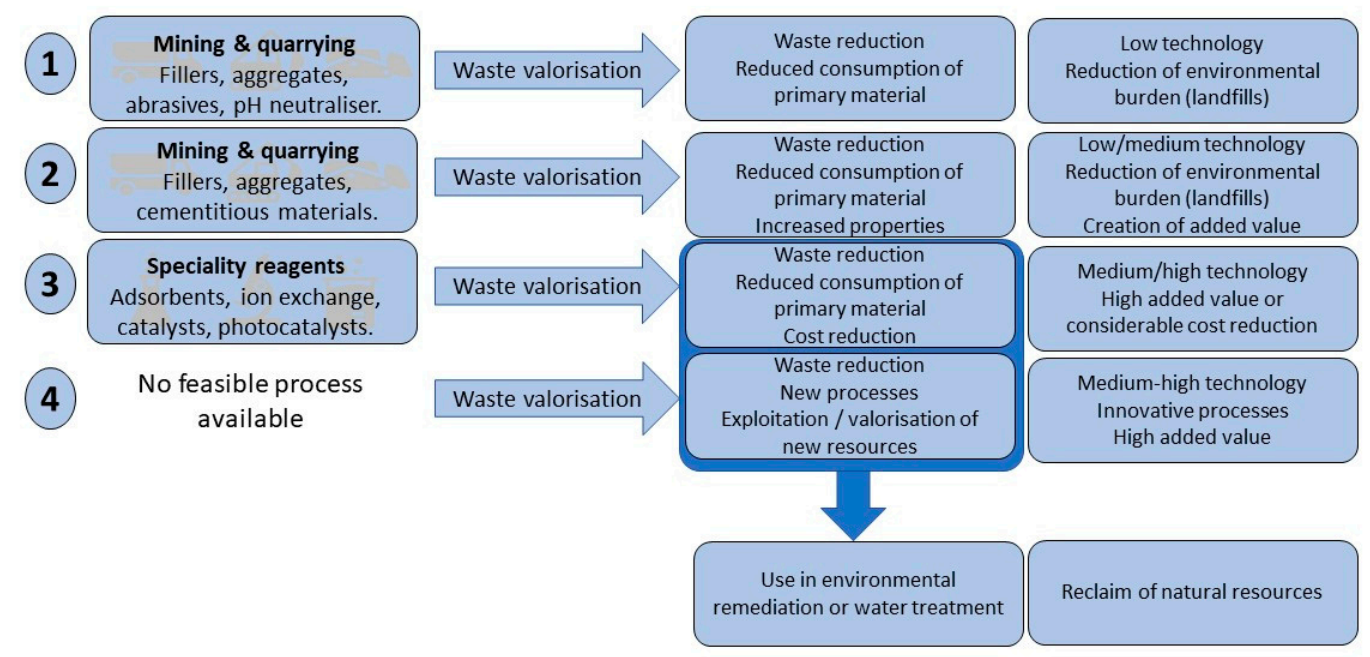

Figure 1. Schematic representation of four technology levels in the valorization of metallurgical slag.

At a second level, the waste material also substitutes for a primary resource, but the resulting material has better properties than the original. Primary resources are conserved and added value is created. In this scenario, the waste material becomes a resource which adds positively to the financial balance of the corresponding industry.

At the third level, the waste is used to substitute for specific high-cost materials. Such applications will be labeled as "high added value" and are typical if the material is used in environmental applications such as pollution removal in water and air. The slags are employed as adsorbents, reagents for ion exchange, or (photo)catalysts. Then, a fourth benefit can be achieved on top of the three already mentioned, by reducing contamination levels in wastewater or reclaiming water resources for further use.

Often, the low-cost alternative of using waste materials will enable the exploitation of resources, which cannot be reclaimed by conventional processes due to prohibitive costs. This defines the fourth level in terms of valorization, as the unique properties of the waste material allow developing applications which are not feasible with conventional materials, or which have prohibitive costs when used in full-scale applications.

The remainder of this paper focuses on Advanced Oxidation Processes (AOPs), specifically in catalytic and photocatalytic applications of metallurgical slags. Section 2 briefly summarizes the fundamental conditions to use as waste product as a photocatalyst for water treatment. Section 3 divides the applications under the topics of ferrous slags, copper slag, magnesium slag, and silicomanganese slag. The high-technology application of slag-based photocatalytic production of hydrogen from wastewater is an emerging topic which is covered at the end of the paper.

\section{Photocatalytic and Advanced Oxidation Processes in Water Treatment}

AOPs are interesting for large-scale water treatment because they do not need costly reagents, and some do not employ sophisticated equipment; also, the processes show high efficiency [46]. Degradation and mineralization of complex organic molecules by AOPs using metallurgical slag is a new approach associated with the development of alternative water treatment methods. One reason is the relatively low market value of water for industrial, agricultural, and domestic consumption, together with the very high volumes to be treated. A logical extension of this research is the photocatalytic hydrogen production from water under UV or solar radiation, using pollutants as sacrificial reagents. A schematic overview of these applications is given in Figure 2. 
Homogeneous Fenton reaction:

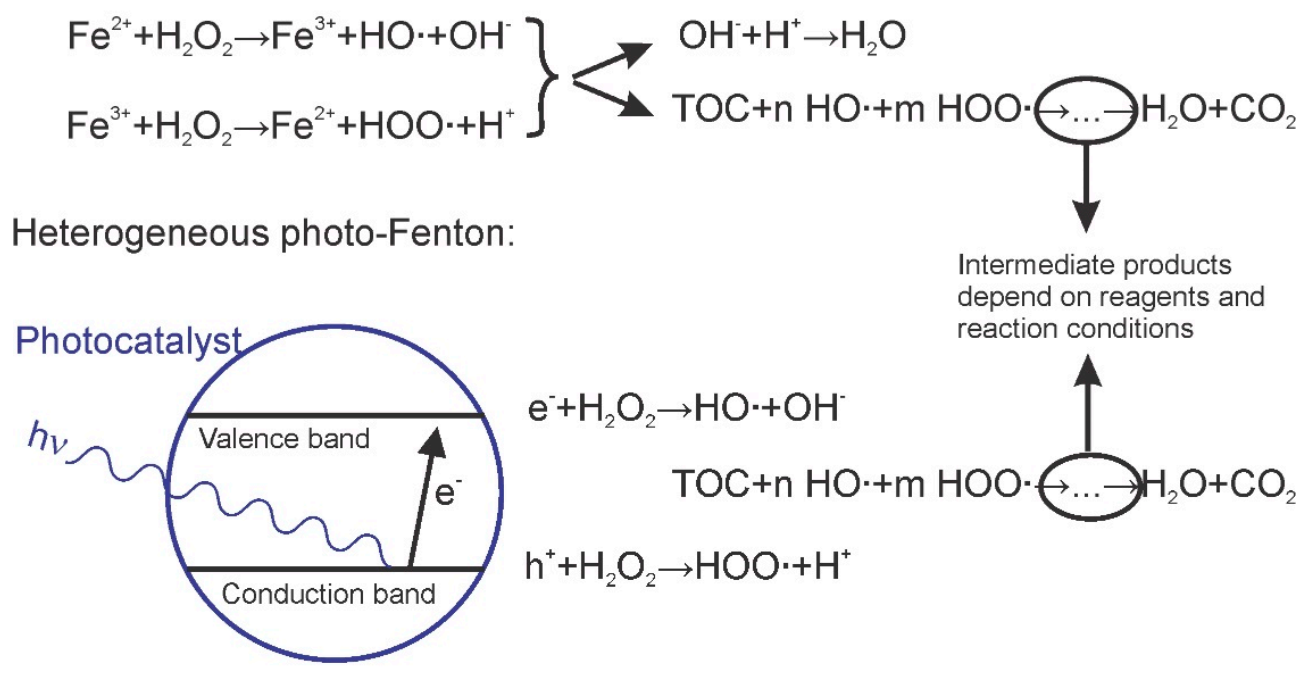

Photocatalytic hydrogen production with sacrificial agent $(\mathrm{SA})$ :

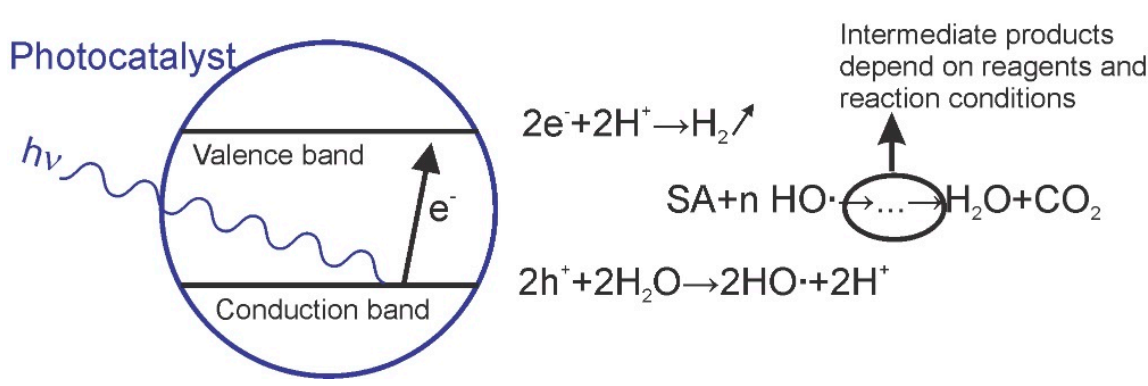

Figure 2. Overview of the advanced oxidation processes achievable using metallurgical slag as a (photo)catalyst. The classical Fenton reaction is given as a reference. Generally, the removal of organic pollutants (OPs) is of interest, which may follow complex reaction paths with a variety of intermediate products; mineralization is often incomplete. In the case of hydrogen production, the organic pollutant is considered as a sacrificial agent (SA).

The well-known homogeneous Fenton reaction employs iron salts and hydrogen peroxide. Hydrogen peroxide $\left(\mathrm{H}_{2} \mathrm{O}_{2}\right)$ is decomposed into hydroxyl radicals under the catalytic effect of $\mathrm{Fe}^{2+}$. The latter ion is soluble in water at a $\mathrm{pH}$ below 2.8, which imposes the use of strongly acidic conditions [47]; at higher $\mathrm{pH}$, the iron is lost as ferric hydroxide sludge.

In the heterogeneous Fenton reaction, the use of solid supports containing iron improves the process. Materials used need to be chemically stable in the reaction environment, to avoid leaching of iron or other metal ions at low $\mathrm{pH}$. The use of solid catalysts containing high levels of iron or iron oxides can overcome this disadvantage. In the photo-Fenton process, irradiation by visible or UV light produces more hydroxyl radicals and increases the rate of degradation of organic pollutants [46]; in addition, the use of sunlight instead of UV radiation reduces cost and increases sustainability.

Organic pollutants are decomposed through oxidation by the highly reactive ${ }^{\bullet} \mathrm{OH}$ radical; in the ensuing reaction chain, additional radicals are created as byproducts of the oxidation to $\mathrm{Fe}^{2+}-\mathrm{Fe}^{3+}$ such as $\mathrm{HO}_{2}{ }^{\bullet}$ (hydroperoxyl) and $\mathrm{O}_{2}{ }^{\bullet}$ (superoxide). The hydroxyl radical is the most powerful species. Generally, it has been proposed that iron oxides present in the slag are responsible for the catalytic activity [48-51]. In the case of biological contaminants, these radicals interact with RNA and with the cell membrane, reducing the viability of the organisms [50].

Photocatalysis is the acceleration of a light-induced reaction [52]. It is generally accepted that photocatalysts are semiconductor materials, where the incidence of a photon with larger energy than 
the band gap of the material produces a jump of an electron $\left(\mathrm{e}^{-}\right)$from the valence band (VB) to the conduction band (CB) with a hole $\left(\mathrm{h}^{+}\right)$remaining in the VB. Donation of a hole (reception of an electron) promotes oxidation of pollutants. On the other hand, the electrons that react with $\mathrm{H}^{+}$coming from organic degradation and water splitting generate gaseous hydrogen. The fundamental principles were reviewed by Liqiang et al. [53] and Chiarello et al. [54], while some essential concepts in the field of photocatalytic chemistry were summarized by Hermann [55].

The most extensively developed class of photocatalysts is based on $\mathrm{TiO}_{2}$, due to its low cost, wide availability, and insensitivity to photocorrosion. Its large band gap (3.2 eV) imposes the use of UV light for its activation, which only presents $4 \%$ of the total energy in the solar spectrum reaching the earth's surface $[56,57]$. Several reviews are available about the modification of this material to shift the band gap to visible light $[54,58-61]$, which often involves expensive processing and may limit the feasibility of their use in large-scale applications.

Typically, catalysts are used as fine-grained to nanosized particles. High specific surface is desirable, as it is assumed that the contaminant must be adsorbed at the surface of the catalyst for the reactions to take place. This condition is probably relaxed in the case of AOPs, where the formation of $\mathrm{OH}$ radicals occurs at the catalyst surface, but breakdown of organic molecules may occur in the bulk of the reactive medium [50,62]. Nanoparticles are a preferable option, but it must be considered that a high density of suspended particles may block out the light source and reduce the efficiency of the process [63-65]. Raceway reactors, where the catalyst is not suspended but rests at the bottom of the raceway with the contaminated water flowing over it, eliminate such considerations but require high amounts of catalysts [66-68]. Here, the development of low-cost alternatives to highly specific nanoparticle materials is particularly interesting.

\section{Development of Photocatalysts from Specific Slags}

\subsection{Photocatalysis Based on Ferrous Slag}

The properties of ferrous slag depend on the production process (iron making, steel making, alloy steels), but also on the origin of the iron ore. Each of these subfields presents opportunities for the development of novel techniques for slag valorization. A first example is provided by a series of studies related to the slag generated from iron ores from the Panzhihua intrusion in southeast China [69]. These ores contain a high concentration of a Ti-V-bearing magnetite, which is exploited for iron production with secondary extraction of vanadium [70].

Slag produced from this ore contains between 21 and $25 \%$ of $\mathrm{TiO}_{2}$ [71]. Acidic and alkaline hydrothermal treatments were developed to extract the titania $\left(\mathrm{TiO}_{2}\right)$. Liu et al. reported the production of anatase nanoparticles by acidolysis of the slag, which was used for the degradation of 2,4-dichlorophenol under UV illumination [72]. Another source of $\mathrm{TiO}_{2}$-based, low-cost photocatalysts is electric arc furnace slag. It was found that acidolysis at very low $\mathrm{pH}(0.05)$ produces nanorod rutile particles which were active as a photocatalyst in the visible spectrum, due to doping of the rutile phase by $\mathrm{Fe}$ and $\mathrm{Si}$ which are present as impurities in the process [73]. At higher $\mathrm{pH}$ values, a mixture of anatase and rutile was obtained which also showed a lower specific surface area [74]. The authors successfully treated contaminants such as rhodamine and methylene blue [75].

Shi et al. [76] produced composite materials in which commercial nanocrystalline titania was supported on a blast furnace slag rich in $\mathrm{Ca}$ and $\mathrm{Si}\left(40.09 \% \mathrm{CaO}, 34.58 \% \mathrm{SiO}_{2}, 14.78 \% \mathrm{Al}_{2} \mathrm{O}_{3}, 5.29 \% \mathrm{MgO}\right.$, $1.53 \% \mathrm{Fe}_{2} \mathrm{O}_{3}, 0.78 \% \mathrm{TiO}_{2}, 0.27 \% \mathrm{MnO}$ ) by means of hydrolysis and thermal treatments. They synthesized a high-purity reference support material from $\mathrm{CaO}$ and $\mathrm{SiO}_{2}$ similar to the slag. The composites (containing 20, 40,60, and $80 \% \mathrm{TiO}_{2}$ ) were used for methylene blue removal under UV irradiation. Higher removal efficiencies were obtained at higher slag contents, while the synthetic material showed lower efficiencies. The authors concluded that the impurities in the slag improved both photocatalytic efficiency and surface area. However, slag without titania could not be used as a photocatalyst in a satisfactory manner. 
The former studies are based on the use of $\mathrm{TiO}_{2}$, which is a well-known photocatalyst. They do not consider the use of the slag as a catalyst on its own. One of the first reports on using a basic oxygen slag in unmodified form in a Fenton process was published by Li et al. [77]. They attribute the efficient degradation of 4-chlorophenol to the dissolution of iron species which catalyze a homogeneous Fenton process at a $\mathrm{pH}$ of 2.8. As such, the slag is, strictly speaking, not a catalyst, as it is slowly consumed during the process.

Nasuha et al. [78] aimed their research toward the catalytic properties of iron oxides in an electric arc furnace slag. They applied a thermo-alkaline treatment, obtaining a mixture of maghemite $\left(\gamma-\mathrm{Fe}_{2} \mathrm{O}_{3}\right)$ and larnite $\left(\mathrm{Ca}_{2} \mathrm{SiO}_{4}\right)$. Degradation tests using a heterogeneous Fenton-like reaction on the synthetic dye reactive black 5 (RB5) were performed using a factorial experimental design involving slag dose, contaminant concentration, $\mathrm{pH}$, and initial hydrogen peroxide concentration, in the absence of illumination. A degradation efficiency of $94 \%$ was obtained at a $\mathrm{pH}$ of 3.0, $0.2 \mathrm{~g} \mathrm{~L}^{-1}$ of catalyst, and $8 \mathrm{mM} \mathrm{H}_{2} \mathrm{O}_{2}$. The material was used for 10 cycles with efficiencies above $90 \%$ and showed negligible lixiviation of $\mathrm{Fe}(0.15 \mathrm{ppm})$.

The same authors analyzed the degradation of Acid Blue 29 (AB29) and methylene blue (MB) at different concentrations, both in dark and under visible light, using a similar experimental design. They noticed an increase in degradation under illumination. Cyclability of the catalyst was found to be lower, leading to the recommendation of substituting this material after seven cycles. One advantage of the slag, as pointed out by the authors, is that it can be recovered from the treated water by magnetic separation. As compared to the work of Shi and coworkers, the work of Nashua proposes a much higher degradation level, shorter reaction times, and simpler preparation mechanisms of the photocatalyst [79].

\subsection{Use of Copper Slag as a Photocatalyst}

The original hypothesis for the use of copper slag (CS) as a photocatalyst was based on its high iron content, which would promote heterogeneous Fenton-like reactions. This hypothesis is now rejected. Huanosta-Guttiérez et al. studied the degradation of phenol using $\mathrm{CS}$ and $\mathrm{H}_{2} \mathrm{O}_{2}$, with and without UV irradiation. They reported up to $50 \%$ reduction in total organic carbon (TOC). During the process, toxicity peaks were observed as the result of the formation of intermediate degradation products. They concluded that the process can be optimized to obtain maximal biodegradability of the residual products, particularly in the presence of the UV source [49].

Solís-López et al. studied the use of a heterogeneous photo-Fenton process for the disinfection of water contaminated by Ascaris suum eggs, where hydroxyl radicals play the role of damaging cell membranes and disrupting the function of RNA during the cell cycle. They suggested that fayalite $\left(\mathrm{Fe}_{2} \mathrm{SiO}_{4}\right)$ was the main actor in the photocatalytic process and that the strongly negative charge of the CS promoted the efficient formation of $\cdot \mathrm{OH}$ radicals under solar irradiation at neutral $\mathrm{pH}$. Under optimal conditions, a 90\% decrease in the viability of the parasite eggs was observed [50].

Arzate-Salgado et al. compared copper slag with steel slag in the degradation of diclofenac under simulated solar radiation and in the presence of $\mathrm{H}_{2} \mathrm{O}_{2}$. While steel slag provided rather modest results, CS reduced the concentration of diclofenac to below the detectability limit of $0.1 \mathrm{mg} \mathrm{L}^{-1}$ in $90 \mathrm{~min}$, with a starting concentration of $120 \mathrm{mg} \mathrm{L}^{-1}$ at neutral $\mathrm{pH}$ [51].

The slag used in these studies was obtained from a smelter in northern Mexico. The first step in the characterization of such material as a catalyst consisted of mechanical grinding and sieving, with the fraction passing through the 400-mesh used in the tests. Morphological characterization was performed using petrographic microscopy (Figure 3) and SEM observation (Figure 4), with phase identification through EDX. XRF and XRD were used to analyze chemical composition and crystalline phases. Characterization of the specific surface area was performed by means of the Brunauer-Emmet-Teller isotherm by adsorption/desorption of $\mathrm{N}_{2}$. The microstructure of the raw copper slag consisted of the orthorhombic fayalite in the form of long needles separated by opaque zones which consisted of a glassy phase (Figure 3). Magnetite was present as small equiaxed particles. This result coincided with 
what was observed by XRD [50]. The morphology of the product after milling is shown in Figure 4 . Here, the fayalite is seen as grey elongated zones, the amorphous phase is dark grey, and the magnetite is present as white equiaxial grains on the particle surface. This morphology can be explained by the normal cooling sequence of CS at intermediate cooling speed [80]. No significant porosity was found for the granular product, which had a specific surface area of $1 \mathrm{~m}^{2} \mathrm{~g}^{-1}$.

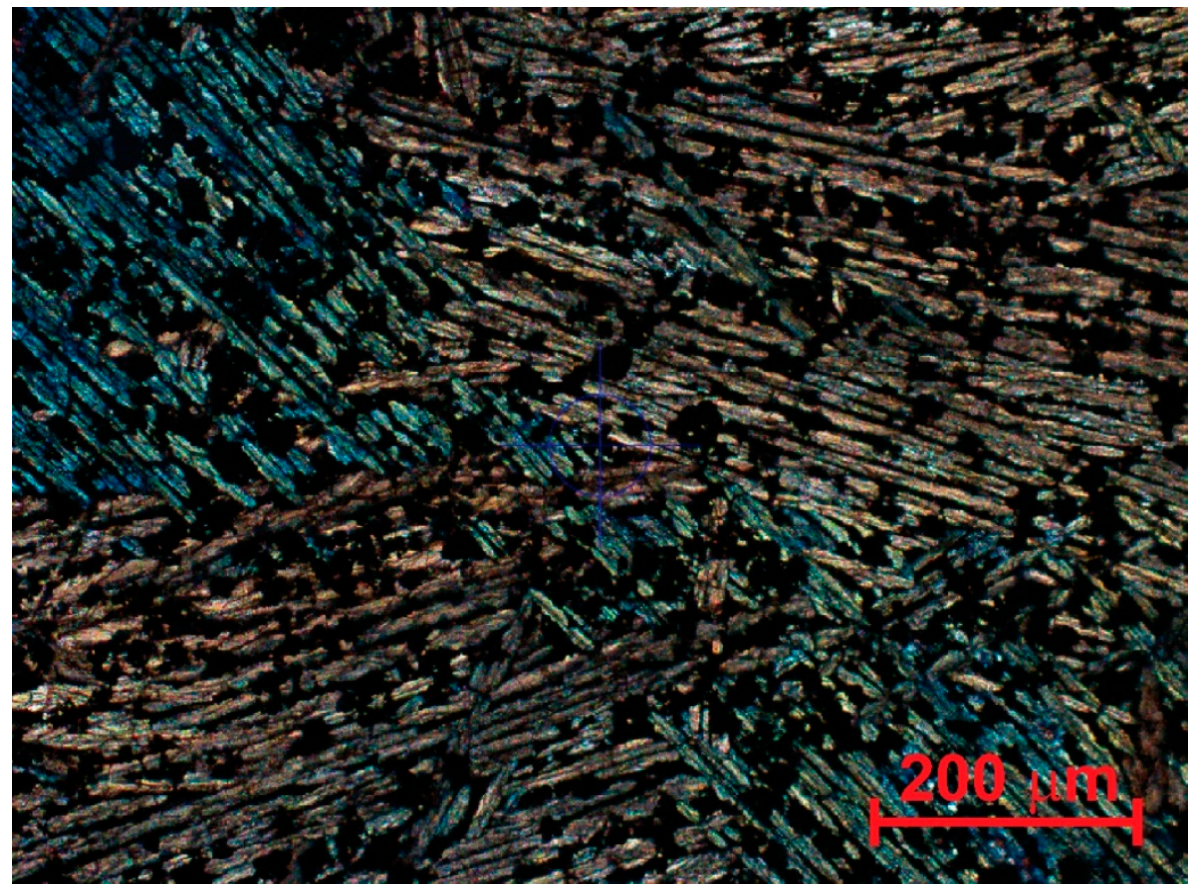

Figure 3. Polarized light observation of CS. Blue/yellow needles correspond to fayalite, elongated dark zones are silicate glass, and the equiaxed dark grains are identified as magnetite.

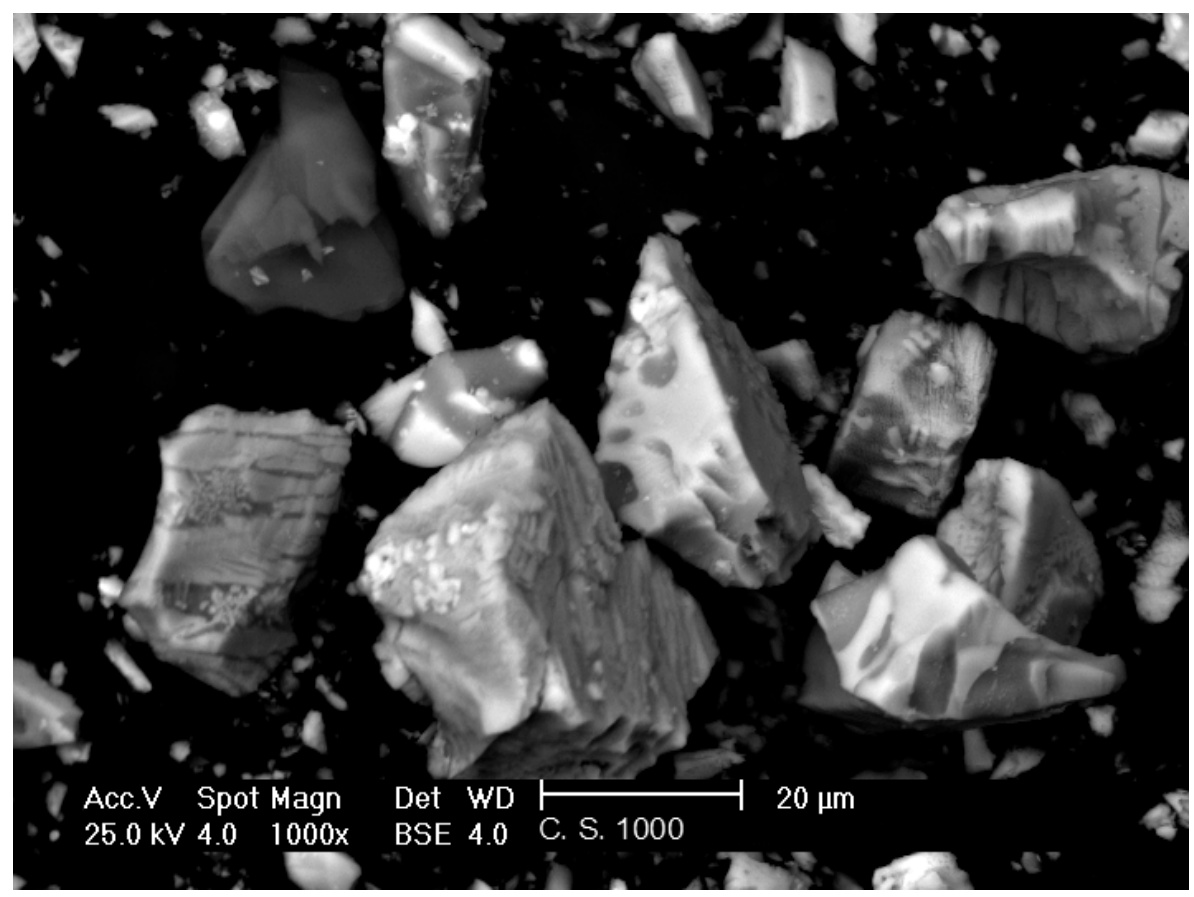

Figure 4. SEM image representing the granulometry of the slag as used in photocatalytic experiments. Fayalite is seen as grey elongated zones, the amorphous phase is dark grey, the magnetite is present as small white equiaxial grains. 
Characterization of a slag for photocatalysis also requires the determination of semiconductor properties. The bandgap can be determined by analysis of the Tauc curve by the Kubelka-Munk equation using data obtained from UV-Vis diffuse reflectance spectroscopy with wavelengths in the range of 200 to $800 \mathrm{~nm}[81,82]$. Electrochemical characterization of the slag has been performed by means of the Mott-Shottky analysis using the techniques described by Ramírez-Ortega et al. [83]. The band gap associated to CS was measured as $2.7 \mathrm{eV}$, which roughly confirms earlier results of $2.5 \mathrm{eV}$ [50]. This value corresponds to literature data for fayalite, as determined from calculation [84] and experiment [85] and rejects earlier hypotheses that the photocatalytic activity was related to magnetite or other iron oxides. The Mott-Shottky analysis shows that CS is an n-type semiconductor, which means that it acts as a hole donor.

The band gap energy of fayalite indicates that CS is active as a photocatalyst under solar light. The amount of Fe leached from the slag into the solution was below the detectability limit $\left(0.25 \mathrm{mg} \cdot \mathrm{L}^{-1}\right.$ $\mathrm{Fe}$ ), showing that the process is heterogeneous photocatalysis and not provoked by leached ions. This combination of a favorable band gap value, inertness of the material in the reaction medium used, and low cost makes it an ideal candidate for the use in raceway reactors. The high efficiency in photo-Fenton processes using this photocatalyst can be explained by its nature as an n-type semiconductor (hole donor). The Fenton reaction is initiated by the splitting of the $\mathrm{H}_{2} \mathrm{O}_{2}$ molecule into either $\cdot \mathrm{OH}+\mathrm{OH}^{-1}$, with the acceptation of an electron from the Fe-based catalyst, or $\cdot \mathrm{OOH}+\mathrm{H}^{+}$, donating an electron to the catalyst. At the surface of an n-type semiconductor, excess holes can be captured, and two hydroxyl radicals can be generated instead of one. In the absence of $\mathrm{H}_{2} \mathrm{O}_{2}$, the degradation kinetics are slower but still significant as $\cdot \mathrm{OH}$ radicals are formed at the surface of the catalyst [49].

\subsection{Photocatalysis Based on Magnesium Slag}

Zhang et al. produced a photocatalyst for the degradation of methyl orange dye. The slag used consisted principally of calcium silicate $\left(\mathrm{Ca}_{2} \mathrm{SiO}_{4}\right)$, wollastonite $\left(\mathrm{CaSiO}_{3}\right)$, and calcium magnesium aluminium oxide silicate $\left(\mathrm{Ca}_{54} \mathrm{MgAl}_{2} \mathrm{Si}_{16} \mathrm{O}_{90}\right)$, which was treated with $\mathrm{Na}_{2} \mathrm{SiO}_{3}$ in aqueous medium followed by an ion-exchange process between $\mathrm{Na}^{+}$and $\mathrm{NH}_{4}{ }^{+}$. A composite material was then produced by aqueous impregnation with $\mathrm{NiO}$ or $\mathrm{CuO}$. They observed that the nanocomposite obtained in this process was capable of degrading $93 \%$ of the dye in $100 \mathrm{~min}$, as opposed to the pure metal oxides, where degradation levels slightly above $50 \%$ were measured, which the authors attributed to a synergic effect between oxides and substrate [86].

In a follow-up study, the authors varied the contents of $\mathrm{NiO}$ and $\mathrm{CuO}$, showing that higher oxide contents improve the photocatalytic activity of the nanocomposite [87]. In this study, UV-Vis diffuse reflectance studies were used to assess the photoelectric characteristics of the composite. They concluded that the oxide species delay electron-hole recombination and enhance the capability for producing the $\cdot \mathrm{OH}$ radicals. Whether the substrate or the oxides were the source of $\mathrm{e}^{-}-\mathrm{h}^{+}$pairs was not addressed.

\subsection{Photocatalysis Based on Silicomanganese Slag}

Compared to the former three materials, silicomanganese slag is produced in much lower volumes. Two interesting catalyst applications have been developed for this waste product. Zhang et al. used thermoalkalic activation in the presence of carbon black, the latter to improve the electron transport in the product. Basic violet $5 \mathrm{BN}$ dye was successfully degraded by the resulting product [88].

In a second work, they developed an electrically conductive geopolymer composite by combining $\mathrm{CaMoO}_{4}$ with ferromanganese slag. In a first step, the geopolymer was synthesized by alkaline hydrothermal treatment in the presence of carbon black. After curing and crushing, a multistep process was developed for the impregnation of this material with $\mathrm{CaMoO}_{4}$. The resulting material showed good electrical conductivity and a maximum photoluminescence in blue wavelengths, which makes it particularly attractive for its use under solar irradiation. They achieved a 99.6\% degradation violet 5BN 
dye in $90 \mathrm{~min}$. The composite catalyst showed a higher efficiency than pure $\mathrm{CaMoO}_{4}$ and commercial catalysts [89].

\subsection{Summary of the Use of Metallurgical Slags in Photocatalysis}

As a summary of Sections 3.1-3.4, Table 1 is presented, which provides an overview of work published in the field.

Table 1. Summary of publications related to the use of metallurgical slag as a catalyst for contaminant degradation.

\begin{tabular}{|c|c|c|c|c|c|}
\hline Slag & $\begin{array}{l}\text { Activation } \\
\text { Treatment }\end{array}$ & $\begin{array}{c}\text { Process of } \\
\text { Degradation }\end{array}$ & Pollutant & $\begin{array}{l}\text { Removal } \\
\text { Efficiency }\end{array}$ & Reference \\
\hline Ferrous & Acid hydrolysis & Photocatalysis & 2-propanol & & [90] \\
\hline Ferrous & Alkaline fusion & Photocatalysis & $20 \mathrm{mg} \mathrm{L}^{-1}$ Methylene blue & $88 \%$ & [73] \\
\hline Ferrous & Acid conditions & Photocatalysis & $5 \mathrm{mg} \mathrm{L}^{-1}$ Rhodamine & $91 \%$ & [74] \\
\hline $\begin{array}{l}\text { Ferrous + } \\
60 \% \mathrm{TiO}_{2}\end{array}$ & $\begin{array}{c}\text { Alkaline } \\
\text { hydrolysis/thermic }\end{array}$ & Photocatalysis & $0.2 \mathrm{mMol} \mathrm{L}^{-1}$ methylene blue & $96.2 \%$ & [76] \\
\hline Ferrous & Alkaline/thermic & Fenton & $25 \mathrm{mg} \mathrm{L}^{-1}$ Black reactive 5 & $94 \%$ & [78] \\
\hline Ferrous & Ball milling & Photocatalysis & $20 \mathrm{mg} \mathrm{L}^{-1} \mathrm{Cr}(\mathrm{VI})$ & $100 \%$ & [91] \\
\hline Ferrous & $\begin{array}{l}\text { Alkaline activation+ } \\
\text { nanocomposite }\end{array}$ & Photocatalysis & $30 \mathrm{mg} \mathrm{L}^{-1}$ DFB dye & $100 \%$ & [88] \\
\hline Ferrous & Alkaline/thermic & Photo-Fenton & $\begin{array}{c}25 \mathrm{mg} \mathrm{L}^{-1} \text { Methylene blue } \\
25 \mathrm{mg} \mathrm{L}^{-1} \text { Blue Acid } 29\end{array}$ & $\begin{array}{l}98 \% \\
94 \%\end{array}$ & [79] \\
\hline Copper & W.T. & Photo-Fenton & $50 \mathrm{mg} \mathrm{L}^{-1}$ phenol & $100 \%$ & [49] \\
\hline Copper & W.T. & Photo-Fenton & Ascaris suum & $58 \%$ & [50] \\
\hline Copper & W.T. & $\begin{array}{l}\text { Photo-Fenton } \\
\text { at neutral pH }\end{array}$ & $30 \mathrm{mg} \mathrm{L}^{-1}$ Diclofenac & $87 \%$ & [51] \\
\hline Magnesium & $\begin{array}{l}\text { Alkaline activation }+ \\
\text { nanocomposite }\end{array}$ & Photocatalysis & $3 \mathrm{mg} \mathrm{L}^{-1}$ methyl orange & $90 \%$ & [92] \\
\hline Magnesium & $\begin{array}{l}\text { Alkaline activation }+ \\
\text { nanocomposite }\end{array}$ & Photocatalysis & $1.07 \times 10^{-4} \mathrm{~mol} \mathrm{~L}^{-1}$ Carmin indigo & $100 \%$ & [86] \\
\hline Silicomanganese & $\begin{array}{l}\text { Alkaline activation+ } \\
\text { carbon black }\end{array}$ & Photocatalysis & $4 \mathrm{mg} \mathrm{L}^{-1}$ basic violet $5 \mathrm{BN}$ & $89 \%$ & [88] \\
\hline Silicomanganese & $\begin{array}{l}\text { Alkaline activation }+ \\
\text { nanocomposite }\end{array}$ & Photocatalysis & $5.64 \mathrm{mg} \mathrm{L}^{-1}$ BV5 dye & $98 \%$ & [89] \\
\hline
\end{tabular}

\section{Hydrogen Production by Wastewater Treatment}

Heterogeneous photocatalytic water treatment can become bifunctional if hydrogen is produced during the degradation of pollutants [58-61]. Hydrogen, as a fuel, has an energy content which is thrice as high as conventional fuels and does not produce $\mathrm{CO}_{2}$ upon combustion. Water reduction or water splitting under solar radiation presents an option to minimize the carbon footprint of $\mathrm{H}_{2}$ production. The pollutant acts a sacrificial agent which fulfils the role of a hole scavenger, preventing electron-hole recombination and promoting the water reduction into hydrogen [93], with the oxygen participating in the degradation of the organic molecules [94].

Zhang and Chai evaluated the use of blast furnace slag for the synthesis of a nanocatalyst by alkaline activation. They found that the activation process produced a mesoporous aggregate consisting mostly of calcium silicate hydrate and calcium aluminum hydrate. They reported the production of $52 \mathrm{mmol} \mathrm{g}^{-1} \mathrm{H}_{2}$ under simulated solar light and attribute the photocatalytic activity to the presence of iron and titanium oxide nanoparticles within the activated slag nanoparticles [95].

Zhang et al. used blast furnace slag which was activated under alkaline conditions and loaded this material with 15 and $5 \% \mathrm{CaWO}_{4}$. They used a $\mathrm{Na}_{2} \mathrm{SO}_{3} / \mathrm{Na}_{2} \mathrm{~S}$ mixture as sacrificial agent and a Xe lamp of $300 \mathrm{~W}$ to simulate solar irradiation. Activated slag and the activated slag loaded with $\mathrm{CaWO}_{4}$ presented the same photoluminescence excitation band at $469 \mathrm{~nm}$ (violet-blue), with a lower intensity at $5 \% \mathrm{CaWO}_{4}$, indicating that this compound inhibits the recombination of electron-hole pairs. They measured bandgap values of $3.92 \mathrm{eV}$ and $3.73 \mathrm{eV}$ for $1 \%$ and $5 \% \mathrm{CaWO}_{4}$, respectively, and a maximum $\mathrm{H}_{2}$ production of $50 \mathrm{mmol} \mathrm{L}^{-1}$ after 6 hours with the latter material [96].

The same research group also reports doping of the activated slag by $\mathrm{CeO}_{2}$ nanoparticles at 1,8 , and $16 \%(\mathrm{wt})$ [97]. This shifts the band gap to between 1.8 and $2.28 \mathrm{eV}$, which allows photocatalysis in the visible spectrum. The material with $8 \% \mathrm{CeO}_{2}$ showed the highest hydrogen production at 
$68 \mathrm{mmol} \mathrm{L}^{-1}$ after 6 hours. They also report on a study where graphene $0.001,0.01$, and $0.02 \%(\mathrm{wt})$ was incorporated at the activated slag surface [98]. Using the same reaction conditions as mentioned before, they obtained a production of $1.9 \mathrm{mmol} \mathrm{L}^{-1} \mathrm{H}_{2}$ for the material with $0.02 \%$ graphene, as compared to $1.4 \mathrm{mmol} \mathrm{L}^{-1} \mathrm{H}_{2}$ without graphene. Further improvement of this catalyst was obtained by incorporation of $\mathrm{ZnO}$ [99].

Sahraei et al. [100] used Ni-impregnated titania-rich slag from an iron-titanium ore for the steam reformation of glycerol, which is a low-value waste from biodiesel production. This material consists mainly of complex metal oxides. The authors found that the resulting catalyst was more efficient in terms of hydrogen production and glycerol conversion than commercial catalysts and showed a superior long-time behavior and cyclability. Dega et al. [101] studied $\mathrm{H}_{2}$ production from methane using the same catalyst, demonstrating a superior behavior with respect to existing commercial catalysts. They attribute this performance to the synergic effect of the complex $\mathrm{Ni}-\mathrm{Fe}-\mathrm{Mg}-\mathrm{Al}$ oxides in the material. The slag-based catalyst is significantly less expensive than commercial alternatives.

The present authors have studied the production of hydrogen with copper slag as a photocatalyst, using glycerol and several alcohols (methanol, propanol, isoamyl alcohol) as a sacrificial agent under UV radiation (Hg lamp) and simulated sunlight (Xe lamp) [101]. For glycerol degradation, $\mathrm{pH}$ was varied from 2 to 12 , slag doses from 0.4 to $2 \mathrm{~g} / \mathrm{L}$, and glycerol concentration from 0.06 to $1.74(\% \mathrm{v} / \mathrm{v})$. For the other three alcohols, the slag dose was fixed at $1 \mathrm{~g} \mathrm{~L}^{-1}, \mathrm{pH}$ at 6.5 , and the initial concentration of alcohols was set at $0.125 \mathrm{M}$. Hydrogen production was monitored for $6 \mathrm{~h}$. The reduction of total organic carbon during the processes was significant, but hydrogen production was low. The latter observation can be explained by the fact that the positively charged $\mathrm{H}^{+}$can be effectively adsorbed on the surface of the n-type semiconductor.

A summary of the publications reporting the use of metallurgical slag for the photocatalytic production of hydrogen is given in Table 2.

Table 2. Use of metallurgical slag as a photocatalyst for hydrogen production.

\begin{tabular}{|c|c|c|c|c|}
\hline Slag & Treatment & Sacrificial Agents & Hydrogen Production & Reference \\
\hline Ferrous & Alkaline activation $+\mathrm{CaWO}_{4}$ & $\mathrm{Na}_{2} \mathrm{SO}_{3}: \mathrm{Na}_{2} \mathrm{~S}(4.36 \mathrm{~g}: 6.25 \mathrm{~g})$ & $50,827 \mu \mathrm{L} \mathrm{g}^{-1}$ & [96] \\
\hline Ferrous & Alkaline activation $+\mathrm{CeO}_{2}$ & $\mathrm{Na}_{2} \mathrm{SO}_{3}: \mathrm{Na}_{2} \mathrm{~S}(4.36 \mathrm{~g}: 6.25 \mathrm{~g})$ & $68 \mathrm{mmol} \mathrm{g}^{-1}$ & [97] \\
\hline Ferrous & Alkaline activation + graphene & $\mathrm{Na}_{2} \mathrm{SO}_{3}: \mathrm{Na}_{2} \mathrm{~S}(4.36 \mathrm{~g}: 6.25 \mathrm{~g})$ & $1.93 \mathrm{mmol} \mathrm{g}^{-1}$ & [98] \\
\hline Ferrous & Alkaline activation $+\mathrm{ZnO}+$ graphene & $\mathrm{Na}_{2} \mathrm{SO}_{3}: \mathrm{Na}_{2} \mathrm{~S}$ & $228.3 \mathrm{mmol} \mathrm{g}^{-1}$ & [99] \\
\hline Copper & Without treatment & Waste alcohols & $0.113 \mu \mathrm{mol} \mathrm{g}-1 \mathrm{~h}^{-1}$ & [102] \\
\hline
\end{tabular}

\section{Conclusions}

In the field of slag valorization, the major body of work is dedicated to the use of slag in building materials which do not normally involve advanced chemical processes or analysis. Use as cementitious materials is more complex and often allows the improvement of the properties of the final product. Recovery of valuable products from slag is the second most important field of research, including the separation of titania as a catalyst for environmental applications. Direct use of the slag in environmental applications, with or without modifications by thermal, mechanical, or chemical processes, represents an expanding field of research, focusing mainly on adsorption, ion exchange, and precipitation.

The use of slag in catalysis has emerged only recently. Two approaches are used. In the first, the slag is modified thermochemically, typically through acidic or alkaline hydrothermal treatment, producing nanoparticles with a large specific surface area and the addition of metal oxides to produce a nanocomposite provides catalytic activity. The most interesting application seems to emerge when nanosized oxides are naturally included as impurities in supporting slag-derived material. The band gap of nanoparticles depends on the particle size and this allows shifting photocatalytic activity from 
UV wavelengths to solar light, which is highly desirable from an economic and environmental point of view.

The second approach is to use the slag in its original state. While this may reduce the price of the slag conditioning process, it has the disadvantage that it produces a material with a low specific area. This disadvantage can be countered by using reactor types with a very large exposure area, such as raceway reactors. In these applications, it is important to correctly identify the semiconductor characteristics of the mineral phases in the slag. The energy levels of the conduction band, in comparison to the absolute oxidation potential for the compounds to be degraded, will determine the feasibility of the process; the magnitude of the band gap will determine the wavelength of the light source to be used.

All works revised in the field of advanced oxidation processes (heterogeneous Fenton processes) emphasize the capability of the photocatalyst to produce hydroxyl radicals, either from $\mathrm{H}_{2} \mathrm{O}$ or $\mathrm{H}_{2} \mathrm{O}_{2}$. For Fenton reactions catalyzed by copper slag, it was observed that fayalite acts as an n-type semiconductor, which increases the $\mathrm{OH}$-yield at the catalytic surface, resulting in a more effective use of the expensive peroxide. Other authors have indicated that nanoparticles of iron and titanium oxides may play the same role.

Most of the processes mentioned in this review are less than five years old and the research field is very new. This means that many innovative applications can be expected, in terms of the slags used, their activation processes, and the contaminants to be treated. None of the applications analyzed seem to have been taken to pilot level, which is indispensable to reach the stage of industrial application. To date, no detailed economic feasibility studies have been published, although most authors agree that slag-based reagents are much cheaper than specialized catalysts for the same processes.

Author Contributions: C.V.M.-B., R.-M.R.-Z., and R.S. conceptualized this review. C.V.M.-B. and E.A. produced the original draft of the manuscript. R.S. and R.-M.R.-Z. supervised and reviewed the manuscript.

Funding: This work was supported by project IV100616 (PAPIIT-DGAPA) and funds from "Instituto de Ingeniería", UNAM.

Acknowledgments: Claudia Montoya thanks CONACYT and PAPIIT project IV100616 for her PhD scholarship. Edwin Avella thanks CONACYT for the scholarship received during his master's studies.

Conflicts of Interest: The authors declare no conflict of interest.

\section{References}

1. Sabbas, T.; Polettini, A.; Pomi, R.; Astrup, T.; Hjelmar, O.; Mostbauer, P.; Cappai, G.; Magel, G.; Salhofer, S.; Speiser, C.; et al. Management of municipal solid waste incineration residues. Waste Manag. 2003, 23, 61-88. [CrossRef]

2. Sakai, S.I.; Hiraoka, M. Municipal solid waste incinerator residue recycling by thermal processes. Waste Manag. 2000, 20, 249-258. [CrossRef]

3. Ecke, H.; Sakanakura, H.; Matsuto, T.; Tanaka, N.; Lagerkvist, A. State-of-the-art treatment processes for municipal solid waste incineration residues in Japan. Waste Manag. Res. 2000, 18, 41-51. [CrossRef]

4. Biswas, S.; Satapathy, A. Use of copper slag in glass-epoxy composites for improved wear resistance. Waste Manag. Res. 2010, 28, 615-625. [CrossRef] [PubMed]

5. Wang, L.; Skjevrak, G.; Hustad, J.E.; Grønli, M.G. Effects of sewage sludge and marble sludge addition on slag characteristics during wood waste pellets combustion. Energy Fuels 2011, 25, 5775-5785. [CrossRef]

6. Zhou, Y.; Zhang, Z.; Zhang, Y.; Wang, Y.; Yu, Y.; Ji, F.; Ahmad, R.; Dong, R. A comprehensive review on densified solid biofuel industry in China. Renew. Sustain. Energy Rev. 2016, 54, 1412-1428. [CrossRef]

7. Rodríguez-Galán, M.; Alonso-Fariñas, B.; Baena-Moreno, F.M.; Leiva, C.; Navarrete, B.; Vilches, L.F. Synthetic Slag Production Method Based on a Solid Waste Mix Vitrification for the Manufacturing of Slag-Cement. Materials 2019, 12, 208. [CrossRef]

8. Worldsteel Association: Steel Industry by-Products. Available online: https://www.worldsteel.org/en/dam/jcr: 1b916a6d-06fd-4e84-b35d-c1d911d18df4/Fact_By-products_2018.pdf (accessed on 1 September 2018). 
9. Qasrawi, H.; Shalabi, F.; Asi, I. Use of low $\mathrm{CaO}$ unprocessed steel slag in concrete as fine aggregate. Constr. Build. Mater. 2009, 23, 1118-1125. [CrossRef]

10. Abu-Eishah, S.I.; El-Dieb, A.S.; Bedir, M.S. Performance of concrete mixtures made with electric arc furnace (EAF) steel slag aggregate produced in the Arabian Gulf region. Constr. Build. Mater. 2012, 34, 249-256. [CrossRef]

11. Maslehuddin, M.; Sharif, A.M.; Shameem, M.; Ibrahim, M.; Barry, M.S. Comparison of properties of steel slag and crushed limestone aggregate concretes. Constr. Build. Mater. 2003, 17, 105-112. [CrossRef]

12. Yüksel, İ. A review of steel slag usage in construction industry for sustainable development. Environ. Dev. Sustain. 2017, 19, 369-384. [CrossRef]

13. Tsakiridis, P.E.; Papadimitriou, G.D.; Tsivilis, S.; Koroneos, C. Utilization of steel slag for Portland cement clinker production. J. Haz. Mater. 2008, 152, 805-811. [CrossRef]

14. Thomas, M.D.; Bamforth, P.B. Modelling chloride diffusion in concrete: Effect of fly ash and slag. Cem. Concr. Res. 1999, 29, 487-495. [CrossRef]

15. Shi, C. Steel slag-Its production, processing, characteristics, and cementitious properties. J. Mater. Civ. Eng. 2004, 16, 230-236. [CrossRef]

16. Vohla, C.; Kõiv, M.; Bavor, H.J.; Chazarenc, F.; Mander, Ü. Filter materials for phosphorus removal from wastewater in treatment wetlands-A review. Ecol. Eng. 2011, 37, 70-89. [CrossRef]

17. Chazarenc, F.; Kacem, M.; Gerente, C.; Andres, Y. Active filters: A mini-review on the use of industrial by-products for upgrading phosphorus removal from treatment wetlands. In Proceedings of the 11th International Conference on Wetland Systems for Water Pollution Control, Indore, India, 1-7 November 2008.

18. Mercado-Borrayo, B.M.; González-Chávez, J.L.; Ramírez-Zamora, R.M.; Schouwenaars, R. Valorization of Metallurgical Slag for the Treatment of Water Pollution: An Emerging Technology for Resource Conservation and Re-utilization. J. Sust. Metal. 2018, 4, 50-67. [CrossRef]

19. Mercado-Borrayo, B.M.; Schouwenaars, R.; González-Chávez, J.L.; Ramírez-Zamora, R.M. Multi-analytical assessment of iron and steel slag characteristics to estimate the removal of metalloids from contaminated water. J. Environ. Sci. Health A 2013, 48, 887-895. [CrossRef]

20. Schouwenaars, R.; Montoya-Bautista, C.V.; Isaacs-Páez, E.D.; Solís-López, M.; Ramírez-Zamora, R.M. Removal of arsenic III and V from laboratory solutions and contaminated groundwater by metallurgical slag through anion-induced precipitation. Environ. Sci. Pollut. Res. 2017, 4, 25034-25046. [CrossRef]

21. Mercado-Borrayo, B.M.; Schouwenaars, R.; Litter, M.I.; Ramirez-Zamora, R.M. Adsorption of boron by metallurgical slag and iron nanoparticles. Adsorpt. Sci. Technol. 2014, 32, 117-123. [CrossRef]

22. Mercado-Borrayo, B.M.; Contreras, R.; Sánchez, A.; Font, X.; Schouwenaars, R.; Ramírez-Zamora, R.M. Optimisation of the removal conditions for heavy metals from water: A comparison between steel furnace slag and CeO2 nanoparticles. Arab. J. Chem. 2018. [CrossRef]

23. Shatokha, V.; Sokur, I.; Kamkina, L.J. Study on water splitting potential of some metallurgical wastes for production of hydrogen. Sustain. Metall. 2016, 2, 116-122. [CrossRef]

24. Das, B.; Mishra, B.K.; Angadi, S.; Pradhan, S.K.; Prakash, S.; Mohanty, J. Characterization and recovery of copper values from discarded slag. Waste Manag. Res. 2010, 28, 561-567. [CrossRef]

25. Behnood, A.; Modiri Gharehveran, M.; Gozali Asl, F.; Ameri, M. Effects of copper slag and recycled concrete aggregate on the properties of CIR mixes with bitumen emulsion, rice husk ash, Portland cement and fly ash. Constr. Building Mater. 2015, 96, 172-180. [CrossRef]

26. Sharma, R.; Khan, R.A. Sustainable use of copper slag in self compacting concrete containing supplementary cementitious materials. J. Clean. Prod. 2017, 151, 179-192. [CrossRef]

27. Sarfo, P.; Wyss, G.; Ma, G.; Das, A.; Young, C. Carbothermal reduction of copper smelter slag for recycling into pig iron and glass. Miner. Eng. 2017, 107, 8-19. [CrossRef]

28. Shanmuganathan, P.; Lakshmipathiraj, P.; Srikanth, S.; Nachiappan, A.L.; Sumathy, A. Toxicity characterization and long-term stability studies on copper slag from the ISASMELT process. Resour. Conserv. Recycl. 2008, 52, 601-611. [CrossRef]

29. Alter, $\mathrm{H}$. The composition and environmental hazard of copper slags in the context of the Basel Convention. Resour. Conserv. Recycl. 2005, 43, 353-360. [CrossRef]

30. Kaksonen, A.H.; Särkijärvi, S.; Peuraniemi, E.; Junnikkala, S.; Puhakka, J.A.; Tuovinen, O.H. Chemical and bacterial leaching of metals from a smelter slag in acid solutions. Hydrometallurgy 2017, 168, 135-140. [CrossRef] 
31. Heo, J.H.; Chung, Y.; Park, J.H. Recovery of iron and removal of hazardous elements from waste copper slag via a novel aluminothermic smelting reduction (ASR) process. J. Clean. Prod. 2016, 137, 777-787. [CrossRef]

32. Dos Anjos, M.A.G.; Sales, A.T.C.; Andrade, N. Blasted copper slag as fine aggregate in Portland cement concrete. J. Environ. Manag. 2017, 196, 607-613. [CrossRef]

33. Shi, C.; Meyer, C.; Behnood, A. Utilization of copper slag in cement and concrete. Resour. Conserv. Recycl. 2008, 52, 1115-1120. [CrossRef]

34. Al-Jabri, K.S.; Al-Saidy, A.H.; Taha, R. Effect of copper slag as a fine aggregate on the properties of cement mortars and concrete. Construct. Build. Mater. 2011, 25, 933-938. [CrossRef]

35. Ambily, P.S.; Umarani, C.; Ravisankar, K.; Prem, P.R.; Bharatkumar, B.H.; Iyer, N.R. Studies on ultra-high performance concrete incorporating copper slag as fine aggregate. Construct. Build. Mater. 2015, 77, 233-240. [CrossRef]

36. Murari, K.; Siddique, R.; Jain, K.K. Use of waste copper slag, a sustainable material. J. Mater. Cycles Waste Manag. 2014, 17, 13-26. [CrossRef]

37. Gorai, B.; Jana, R.K. Characteristics and utilisation of copper slag-A review. Resour. Conserv. Recycl. 2003, 39, 299-313. [CrossRef]

38. United States Geological Survey. Magnesium Statistics and Information. Available online: https://minerals. usgs.gov/minerals/pubs/commodity/magnesium/ (accessed on 30 August 2018).

39. Cherubini, F.; Raugei, M.; Ulgiati, S. LCA of magnesium production: Technological overview and worldwide estimation of environmental burdens. Resour. Conserv. Recycl. 2008, 52, 1093-1100. [CrossRef]

40. Jia, L.; Fan, B.G.; Huo, R.P.; Li, B.; Yao, Y.X.; Han, F.; Qiao, X.L.; Jin, Y. Study on quenching hydration reaction kinetics and desulfurization characteristics of magnesium slag. J. Clean. Prod. 2018, 190, 12-23. [CrossRef]

41. Nath, S.K.; Kumar, S. Evaluation of the suitability of ground granulated silico-manganese slag in Portland slag cement. Construct. Build. Mater. 2016, 125, 127-134. [CrossRef]

42. Nath, S.K.; Kumar, S. Reaction kinetics, microstructure and strength behavior of alkali activated silico-manganese (SiMn) slag-Fly ash blends. Construct. Build. Mater. 2017, 147, 371-379. [CrossRef]

43. Kozyrev, N.A.; Kryukov, R.E.; Kozyreva, O.E.; Lipatova, U.I.; Filonov, A.V. Production of welding fluxes using waste slag formed in silicomanganese smelting. In IOP Conference Series: Materials Science and Engineering; IOP Publishing Ltd.: Bristol, UK, 2016; Volume 125, p. 012034.

44. Kozyrev, N.A.; Mikhno, A.R.; Kryukov, R.E.; Yakushevich, N.F.; Provodova, A.A. Use of barium-strontium modifier in manufacturing welding flux based on silicomanganese slag for welding and surfacing mining equipment. In IOP Conference Series: Earth and Environmental Science; IOP Publishing Ltd.: Bristol, UK, 2018; Volume 206, p. 012033.

45. Yi, H.; Xu, G.; Cheng, H.; Wang, J.; Wan, Y.; Chen, H. An overview of utilization of steel slag. Procedia Environ. Sci. 2012, 16, 791-801. [CrossRef]

46. Ameta, R.; Chohadia, A.K.; Jain, A.; Punjabi, P.B. Fenton and Photo-Fenton Processes; Ameta, R., Ed.; Elsevier and Academic Press: Rajastan, India, 2018; pp. 49-87.

47. Pignatello, J.J.; Oliveros, E.; MacKay, A. Advanced Oxidation Processes for Organic Contaminant Destruction Based on the Fenton Reaction and Related Chemistry. Crit. Rev. Env. Sci. Technol. 2006, 36, 1-84. [CrossRef]

48. Morales-Pérez, A.A.; Maravilla, P.; Solís-López, M.; Schouwenaars, R.; Durán-Moreno, A.; Ramírez-Zamora, R.M. Optimization of the synthesis process of an iron oxide nanocatalyst supported on activated carbon for the inactivation of Ascaris eggs in water using the heterogeneous Fenton-like reaction. Water Sci. Technol. 2016, 73, 1000-1009.

49. Huanosta-Gutiérrez, T.; Dantas, R.F.; Ramírez-Zamora, R.M.; Esplugas, S. Evaluation of copper slag to catalyze advanced oxidation processes for the removal of phenol in water. J. Haz. Mater. 2012, 213, 325-330. [CrossRef]

50. Solís-López, M.; Durán-Moreno, A.; Rigas, F.; Morales, A.A.; Navarrete, M.; Ramírez-Zamora, R.M. Assessment of copper slag as a sustainable Fenton-type photo-catalyst for water disinfection. Water Reclam. Sustain. 2014, 199-227.

51. Arzate-Salgado, S.Y.; Morales-Pérez, A.A.; Solís-López, M.; Ramírez-Zamora, R.M. Evaluation of metallurgical slag as a Fenton-type photocatalyst for the degradation of an emerging pollutant: Diclofenac. Catal. Today 2016, 266, 126-135. [CrossRef] 
52. Saravanan, R.; Gracia, F.; Stephen, A. Basic principles, mechanism and challenges of photocatalysis. In Nanocomposites for Visible Light-induced Photocatalysis; Khan, M., Pradhan, D., Sohn, Y., Eds.; Springer Series on Polymer and Composite Materials; Springer: Cham, Switzerland, 2017.

53. Liqiang, J.; Xiaojun, S.; Jing, S.; Weimin, C.; Zili, X.; Yaoguo, D.; Honggang, F. Review of surface photovoltage spectra of nano-sized semiconductor and its applications in heterogeneous photocatalysis. Sol. Energy Mater. Sol. Cells 2003, 79, 133-151. [CrossRef]

54. Chiarello, G.-L.; Aguirre, M.; Selli, E. Hydrogen production by photocatalytic steam reforming of methanol on noble metal-modified $\mathrm{TiO}_{2}$. J. Catal. 2010, 273, 182-190. [CrossRef]

55. Herrmann, J.M. Fundamentals and misconceptions in photocatalysis. J. Photochem. Photobiol. A Chem. 2010, 216, 85-93. [CrossRef]

56. Pelaez, M.; Nolan, N.T.; Pillai, S.C.; Seery, M.K.; Falaras, P.; Kontos, A.G.; Dunlop, P.S.M.; Hamilton, J.W.J.; Byrne, J.A.; O'Shea, K.; et al. A review on the visible light active titanium dioxide photocatalysts for environmental applications. Appl. Catal. B Environ. 2012, 125, 331-349. [CrossRef]

57. Schneider, J.; Matsuoka, M.; Takeuchi, M.; Zhang, J.; Horiuchi, Y.; Anpo, M.; Bahnemann, D.W. Understanding $\mathrm{TiO}_{2}$ Photocatalysis: Mechanisms and Materials. Chem. Rev. 2014, 114, 9919-9986. [CrossRef]

58. Chen, X.; Shen, S.; Guo, L.; Mao, S.S. Semiconductor-based photocatalytic hydrogen generation. Chem. Rev. 2010, 110, 6503-6570. [CrossRef] [PubMed]

59. Spasiano, D.; Marotta, R.; Malato, S.; Fernandez-Ibañez, P.; Somma, I.D. A review of solar photocatalysis: Materials, reactors, some commercial, and pre-industrialized applications. A comprehensive approach. Appl. Catal. B Environ. 2015, 170-171, 90-123. [CrossRef]

60. Chong, M.N.; Jin, B.; Chow, C.W.K.; Saint, C. Recent developments in photocatalytic water treatment technology: A review. Water Res. 2010, 44, 2997-3027. [CrossRef] [PubMed]

61. Dozzi, M.V.; Chiarello, G.L.; Pedroni, M.; Livraghi, S.; Giamello, E.; Selli, E. High photocatalytic hydrogen production on $\mathrm{Cu}(\mathrm{II})$ pre-grafted $\mathrm{Pt} / \mathrm{TiO}_{2}$. Appl. Catal. B 2017, 209, 417-428. [CrossRef]

62. Wang, W.; Qu, Y.; Yang, B.; Liu, X.; Su, W. Lactate oxidation in pyrite suspension: A Fenton-like process in situ generating $\mathrm{H}_{2} \mathrm{O}_{2}$. Chemosphere 2012, 86, 376-382. [CrossRef] [PubMed]

63. Hakamizadeh, M.; Afshar, S.; Tadjarodi, A.; Khajavian, R.; Fadaie, M.R.; Bozorgi, B. Improving hydrogen production via water splitting over $\mathrm{Pt} / \mathrm{TiO}_{2} /$ activated carbon nanocomposite. Int. J. Hydrogen Energy 2014, 39, 7262-7269. [CrossRef]

64. Onsuratoom, S.; Chavadej, S.; Sreethawong, T. Hydrogen production from water splitting under UV light irradiation over Ag-loaded mesoporous-assembled $\mathrm{TiO}_{2}-\mathrm{ZrO}_{2}$ mixed oxide nanocrystal photocatalysts. Int. J. Hydrogen Energy 2011, 36, 5246-5261. [CrossRef]

65. Zhu, Z.; Chen, J.-Y.; Su, K.-Y.; Wu, R.-J. Efficient hydrogen production by water-splitting over Pt-deposited $\mathrm{C}-\mathrm{HS}-\mathrm{TiO}_{2}$ hollow spheres under visible light. J. Taiwan Inst. Chem. Eng. 2016, 60, 222-228. [CrossRef]

66. Rivas, G.; Carra, I.; Sánchez, J.G.; López, J.C.; Malato, S.; Pérez, J.S. Modelling of the operation of raceway pond reactors for micropollutant removal by solar photo-Fenton as a function of photon absorption. Appl. Catal. B Environ. 2015, 178, 210-217. [CrossRef]

67. De la Obra, I.; Ponce-Robles, L.; Miralles-Cuevas, S.; Oller, I.; Malato, S.; Pérez, J.S. Microcontaminant removal in secondary effluents by solar photo-Fenton at circumneutral $\mathrm{pH}$ in raceway pond reactors. Catal. Today 2017, 287, 10-14. [CrossRef]

68. Freitas, A.M.; Rivas, G.; Campos-Mañas, M.C.; López, J.C.; Agüera, A.; Pérez, J.S. Ecotoxicity evaluation of a WWTP effluent treated by solar photo-Fenton at neutral $\mathrm{pH}$ in a raceway pond reactor. Environ. Sci. Pollut. Res. 2017, 24, 1093-1104. [CrossRef] [PubMed]

69. Zhou, M.F.; Robinson, P.T.; Lesher, C.M.; Keays, R.R.; Zhang, C.J.; Malpas, J. Geochemistry, petrogenesis and metallogenesis of the Panzhihua gabbroic layered intrusion and associated Fe-Ti-V oxide deposits, Sichuan Province, SW China. J. Petrol. 2005, 46, 2253-2280. [CrossRef]

70. Taylor, P.R.; Shuey, S.A.; Vidal, E.E.; Gomez, J.C. Extractive metallurgy of vanadium-containing titaniferrous magnetite ores: A review. Miner. Metall. Proc. 2006, 23, 80-86.

71. Liu, S.L.; Yang, S.L.; Gao, S.Z. The trend of technology progress and development on extraction of Panzhihua high titanium blast furnace slag. Panzhihua Sci. Technol. Inf. 2006, 31, 10.

72. Liu, H.; Xia, T.; Shon, H.K.; Vigneswaran, S. Preparation of titania-containing photocatalyst from metallurgical slag waste and photodegradation of 2,4-dichlorophenol. J. Ind. Eng. Chem. 2011, 117, 461-467. [CrossRef] 
73. Li, Y.; Yue, Y.; Que, Z.Q.; Zhang, M.; Guo, M. Preparation and visible-light photocatalytic property of nanostructured $\mathrm{Fe}$-doped $\mathrm{TiO}_{2}$ from titanium containing electric furnace molten slag. Int. J. Miner. Metall. Mater. 2013, 20, 1012-1020. [CrossRef]

74. Li, Y.; Liu, L.; Guo, M.; Zhang, M. Synthesis of $\mathrm{TiO}_{2}$ visible light catalysts with controllable crystalline phase and morphology from Ti-bearing electric arc furnace molten slag. J. Environ. Sci. 2016, 47, 14-22. [CrossRef]

75. Li, Y.; Yang, Y.; Guo, M.; Zhang, M. Influence of acid type and concentration on the synthesis of nanostructured titanium dioxide photocatalysts from titanium-bearing electric arc furnace molten slag. RSC Adv. 2015, 5, 13478-13487. [CrossRef]

76. Shi, J.; Kuwahara, Y.; An, T.; Yamashita, H. The fabrication of $\mathrm{TiO}_{2}$ supported on slag-made calcium silicate as low-cost photocatalyst with high adsorption ability for the degradation of dye pollutants in water. Catal. Today 2017, 281, 21-28. [CrossRef]

77. Li, Y.S. The use of waste basic oxygen furnace slag and hydrogen peroxide to degrade 4-chlorophenol. Waste Manag. 1999, 19, 495-502. [CrossRef]

78. Nasuha, N.; Ismail, S.; Hameed, B.H. Activated electric arc furnace slag as an efficient and reusable heterogeneous Fenton-like catalyst for the degradation of Reactive Black 5. J. Taiwan Inst. Chem. Eng. 2016, 67, 235-243. [CrossRef]

79. Nasuha, N.; Ismail, S.; Hameed, B.H. Activated electric arc furnace slag as an effective and reusable Fenton-like catalyst for the photodegradation of methylene blue and acid blue 29. J. Environ. Manag. 2017, 196, 323-329. [CrossRef]

80. Wang, X.; Geysen, D.; Padilla Tinoco, S.V.; D’Hoker, N.V.G.T.; Van Gerven, T.; Blanpain, B. Characterisation of copper slag in view of metal recovery. Miner. Proc. Extract. Metall. 2015, 124, 83-87. [CrossRef]

81. Escobedo, A.; Sánchez, E.; Pal, U. Use of diffuse reflectance spectroscopy for optical characterization of un-supported nanostructures. Rev. Mex. De Física 2007, 53, 18-22.

82. López, R.; Gómez, R. Band-gap energy estimation from diffuse reflectance measurements on sol-gel and commercial $\mathrm{TiO}_{2}$ : A comparative study. J. Sol-Gel Sci. Technol. 2011, 61, 1-7. [CrossRef]

83. Ramírez-Ortega, D.; Meléndez, A.; Acevedo-Peña, P.; González, I.; Arroyo, R. Semiconducting properties of $\mathrm{ZnO} / \mathrm{TiO}_{2}$ composites by electrochemical measurements and their relationship with photocatalytic activity. Electrochim. Acta 2014, 140, 541-549. [CrossRef]

84. Cococcioni, M.; De Gironcoli, S. Linear response approach to the calculation of the effective interaction parameters in the LDA+ U method. Phys. Rev. B 2005, 71, 035105. [CrossRef]

85. Williams, Q.; Knittle, E.; Reichlin, R.; Martin, S.; Jeanloz, R. Structural and electronic properties of $\mathrm{Fe}_{2} \mathrm{SiO}_{4}$-fayalite at ultrahigh pressures: Amorphization and gap closure. J. Geophys. Res. Solid Earth 1990, 95, 21549-21563. [CrossRef]

86. Zhang, Y.J.; Kang, L.; Liu, L. A Novel Magnesium Slag-Based Cementitious Nano-Composite for Photocatalytic Degradation of Dye. Rare Met. Mater. Eng. 2015, 44, 3032-3036.

87. Zhang, Y.J.; Kang, L.; Liu, L.C.; Si, H.X.; Zhang, J.F. Synthesis of a novel alkali-activated magnesium slag-based nanostructural composite and its photocatalytic performance. App. Surf. Sci. 2015, 331, 399-406. [CrossRef]

88. Zhang, Y.J.; He, P.Y.; Chen, H.; Liu, L.C. Green transforming metallurgical residue into alkali-activated silicomanganese slag-based cementitious materials as photocatalyst. Materials 2018, 11, 1773. [CrossRef]

89. He, P.Y.; Zhang, Y.J.; Chen, H.; Liu, C.L. Development of an eco-efficient $\mathrm{CaMoO}_{4} /$ electroconductive geopolymer composite for recycling silicomanganese slag and degradation of dye wastewater. J. Clean. Prod. 2019, 208, 1476-1487. [CrossRef]

90. Kuwahara, Y.; Kamegawa, T.; Mori, K.; Yamashita, H. Fabrication of hydrophobic zeolites using triethoxyfluorosilane and their application as supports for $\mathrm{TiO}_{2}$ photocatalysts. Chem. Commun. 2008, 4783-4785. [CrossRef]

91. Lei, X.-F.; Xue, X.-X.; Yang, H. Preparation of UV/Visible light responsive photocatalyst from titania-bearing blast furnance slag modified with $\left(\mathrm{NH}_{4}\right)_{2} \mathrm{SO}_{4}$. Trans. Nonferr. Metal. Soc. China 2012, 22, 1771-1777. [CrossRef]

92. Zhang, Y.J.; Yang, M.Y.; Zhang, L.; Zhang, K.; Kang, L. A new graphene/geopolymer nanocomposite for degradation of dye wastewater. Integr. Ferroelectr. 2015, 171, 38-45. [CrossRef]

93. Bowker, M.; Bahruji, H.; Kennedy, J.; Jones, W.; Hartley, G.; Morton, C. The Photocatalytic Window: Photo-Reforming of Organics and Water Splitting for Sustainable Hydrogen Production. Catal. Lett. 2015, 145, 214-219. [CrossRef] 
94. Dincer, I.; Acar, C. Review and evaluation of hydrogen production methods for better sustainability. Int. J. Hydrogen Energy 2014, 40, 11094-11111. [CrossRef]

95. Zhang, Y.J.; Chai, Q. Alkali-activaded blast furnace slag-based nanomaterial as a novel catalyst for synthesis of hydrogen fuel. Fuel 2014, 115, 84-87. [CrossRef]

96. Zhang, Y.L.; Zhang, L.; Kang, L.; Yang, M.Y.; Zhang, K. A new CaWO 4 /alkali-activated blast furnace slag-based cementitious composite for production of hydrogen. Int. J. Hydrogen Energy 2017, 42, 3690-3697. [CrossRef]

97. Kang, L.; Zhang, Y.J.; Zhang, L.; Zhang, K. Preparation, characterization and photocatalytic activity of novel $\mathrm{CeO}_{2}$ loaded porus alkali-activated steel slag-based binding material. Int. J. Hydrogen Energy 2017, 42, 17341-17349. [CrossRef]

98. Zhang, Y.J.; Zhang, Y.X.; Yang, M.Y. Synthesis of environment-friendly graphene reinforced slag-based nanocomposite and performance of photocatalytic $\mathrm{H}_{2}$ generation. Ferroelectrics 2018, 522, 36-44. [CrossRef]

99. Zhang, Y.J.; He, P.Y.; Yang, M.Y.; Chen, H.; Liu, L.C. Renewable conversion of slag to graphene geopolymer for $\mathrm{H}_{2}$ production and wastewater treatment. Catal. Today 2019. [CrossRef]

100. Sahraei, O.A.Z.; Larachi, F.; Abatzoglou, N.; Iliuta, M.C. Hydrogen production by glycerol steam reforming catalyzed by Ni-promoted Fe/Mg-bearing metallurgical wastes. Appl. Catal. B Environ. 2017, 219, 183-193. [CrossRef]

101. Dega, F.B.; Chamoumi, M.; Braidy, N.; Abatzoglou, N. Autothermal dry reforming of methane with a nickel spinellized catalyst prepared from a negative value metallurgical residue. Renew. Energy 2019, 138, 1239-1249. [CrossRef]

102. Montoya-Bautista, C.V.; Acevedo, P.; Zanella, P.; Schouwenaars, R.; Ramirez-Zamora, R.M. Degradation of waste alcohols with a concurrent hydrogen production using copper slag as photocatalyst. Environ. Sci. Pollut. Res. 2018. submitted. 